\author{
Asian Journal of Economic Modelling \\ $\operatorname{ISSN}(e): \quad 2312-3656$ \\ $\operatorname{ISSN}(p): \quad 2313-2884$ \\ DOI: 10.18488/journal.8.2014.21.1.17 \\ Vol. 2, No. 1, 1-17 \\ (C) 2014. AESS Publications. All Rights Reserved. \\ URL: wwrw.aessweb.com
}

\title{
MODELING THE EFFECTS OF MOTHER'S AGE AT FIRST BIRTH ON CHILD HEALTH AT BIRTH
}

Mbu Daniel Tambi ${ }^{1}$

'Department of Agricultural Economics, University of Dschang, Cameroon.

(+ Corresponding author)

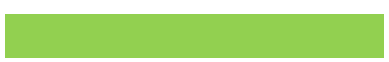

Article History

Received: $\mathrm{xxxxxxxxx}$

Revised: $\mathrm{xxxxxx \times xx}$

Accepted: $\mathrm{xxxxxxxxx}$

Published: $\operatorname{xxx} x \times x \times x x$

Keywords

Birth weight

Cameroon

Child health

Control function

Modeling

Mother's age.

\begin{abstract}
This study models the impact of mother's age at first birth on child health at birth in Cameroon. The objectives are: (1) investigate the implication of mother's age at first birth on child health at birth; (2) examine the impact of mother's age groups on birth weight, and (3) suggest economic policies to ameliorate the mother's age - child health relationship. We make used of the control function approach to determine the relationship between mother's age at first birth and birth weight. The 2011 Cameroon demographic and health survey data is use to estimate our result in STATA 10.1. The result reveals that mother's age at first birth is negatively correlating with birth weight. Evidences by age group suggest that rates of adverse perinatal outcome such as low birth weight and stillbirth are linked to maternal age 35-39 years old. Based on our results, we recommend that aspiring mothers should endeavour to give birth to their first child before 35 years while mother's already advanced in age should follow closely their prenatal and medical services. This is a major step towards poverty alleviation due to low birth weight complications.
\end{abstract}

\section{INTRODUCTION}

Child health and maternal health is at the centre of economic policy today. A country's productive capacity is strongly determine by the health quality of the population, it's therefore imperative to examine the intricacies, determinants and issues surrounding this area of study. The mean age of mothers at first child's birth is defined as the average completed year of age of women when their first child is born. For a given calendar year, the mean age of women at first birth is calculated using the fertility rates for first births by age. Mwabu (2009) noted that in addition to being a metric for measuring health status, birth weight is an indicator of economic and social well-being. Thus, Alderman and Behrman (2004) listed six economic benefits of 
increasing birth weight in developing countries, namely: (i) reduced infant mortality, (ii) reduced cost of neonatal care, (iii) reduced cost of childhood illnesses, (iv) productivity gain from increased cognitive ability, (v) reduced cost of chronic diseases in adults and (vi) better intergenerational health.

Carolan and Frankowska (2010) revealed that in the past two decades, trends of delayed child bearing have become increasingly common in high income countries (Bre art et al., 2003; Ventura et al., 2009), and women are now having fewer babies and commencing child bearing at a later age (Berryman et al., 1999). Average age of first birth has increased significantly and the greatest increase is seen among women aged 35-39 years (Mortensen et al., 2009). Child bearing women over 35 years of age are today more likely to be well educated (Carolan, 2003), of higher socioeconomic status (Berryman et al., 1999; Hammarberg and Clarke, 2005) and of low parity (Joseph et al., 2007), in contrast to their earlier peers who were more likely to be of lower socioeconomic status and of high parity (Wildschut, 1999). Moreover, contemporary child bearing women aged 43 years are more likely to be healthy and to exercise prudent health choices (Viau $e t$ al., 2002; Carolan, 2003), and these factors, together with higher education and higher socioeconomic status, are associated with better perinatal and neonatal outcomes, such as term birth and normal birth weight (Joseph et al., 2007; Mortensen et al., 2009).

It has already been proven in the medical literature that, women become less fertile as they age because they begin life with a fixed number of eggs in their ovaries, the number decreases as they grow older, eggs also are not as easily fertilized in older women as they are in younger women.

Problems that can affect fertility, such as endometriosis and uterine fibroids become more common with increasing age. Becoming pregnant after 35 years can present a challenge and having a child later in life has certain risk. These risks may affect a woman's health as well as her baby's health $(\mathrm{FAQ}, 2012)$; therefore, older women are more likely to have pre-existing health problems than younger women, for example, if a woman is older than 35 years, there is a high probability of developing High Blood Pressure (HBP) and related disorders for the first time during pregnancy.

HBP poses risks that include problems with the placenta and the growth of the fetus and if a mother has diabetes, there is greater risk of having a child with birth defects.

Many authors have examined the relationship between age and infants' health at birth. Among the measures of health status considered are: rates of stillbirth, neonatal and infant mortality, birth weights, birth lengths, Apgar scores, and scores based on the Brazelton Neonatal Behavioural Assessment Scales. In part owing to the variety of measures used, these studies have yielded an inconsistent picture of the relationship between maternal age and infant health status (Rothenberg and Varga, 1981). Prematurity and low birthweight are perhaps the most frequently cited adverse outcomes to children of young mothers. For example, in a study of more than 13,000 births in Scotland, Douglas (1950) reported that the highest frequency of children with birthweights lower than 2500 grams occurred among women less than 20 years of age. Similarly, in their study at Johns Hopkins Hospital, Battaglia et al. (1963) found increased rates of both prematurity and low birthweight (less than 1000 grams) among women who gave birth before 15 
years of age. In a later study conducted at the same hospital, (Hardy et al.) reported the mean birthweight of infants of women 16 years old or younger to be 130 grams lower than that of children of older mothers. Lobl et al. (1971) have also reported positive relationships between maternal age and infant birthweight.

Issues on mother's age and birthweight relationship have been documented more in the medical literature and in advanced countries. In Sub Saharan Africa we have not yet come across any major study that have dealt on this, hence this study has filled this literature gap in informing the government and non-state actors working on child health to develop appropriate policies to addressing reproductive health intricacies. To do this, the objectives are: (1) investigate the implication of mother's age at first birth on child health at birth; (2) examine the impact of mother's age groups on birth weight, and (3) suggest economic policies to ameliorate the mother's age - child health relationship.

The rest of this work is divided such that section 2 deals with the literature review, section 3 the theoretical framework and methodology, section 4 discusses the data setting while section 5 and 6 presents the empirical results and conclusion respectively.

\section{LITERATURE REVIEW}

Oyefara (2010) examined the nexus between maternal age at first birth and level of childhood mortality and observed a significant relationship between maternal age at first birth and childhood mortality level within the socio-demographic characteristics of women. He realized that, women who had their first birth below 20 years exhibited significant higher number of childhood mortality as compared to women who had their first birth by age 20. Implying that, age at first birth is a strong determinant of relatively high childhood mortality level in the study area.

Considering Eurostat (2012) in 2009, the mean age of women at the birth of their first child varied significantly across OECD countries from 21.3 years of age in Mexico to 30.5 years in New Zealand. (Rychtarikova et al., 2004) revealed that the effect of maternal age on the outcome of pregnancy may be best assessed by examining five specific factors that can negatively affect the desired outcome of a pregnancy: (1) a healthy mother and a healthy baby, (2) declining fertility, (3) miscarriage, (4) chromosomal abnormalities, (5) hypertensive complications and stillbirth. They noted that maternal death, the risk of which also increases with age, is fortunately so rare that it does not factor into their discussion. They also noted the relationship between maternal age and miscarriage rates. At 20 years of age, the rate is about 10 percent; it increases more than 90 percent among women 45 years of age or older. This high miscarriage rate contributes significantly to decreasing fertility among older women. Further, Rychtarikova et al. (2013) mentioned that late parental ages at child bearing are associated with infant mortality, especially neonatal and early neonatal mortality (Wunsch and Gourbin, 2002) and with late fetal mortality.

Rothenberg and Varga (1981) investigated the relationship between age of mother and children's health and development at birth and at approximately three years of age. The sample is composed of Black and Hispanic women and their first born children who were delivered on the wards of a large New York City hospital in 1975. There were no differences between children of teenage and older mothers in terms of prematurity or birth weight, but the children of younger 
mothers had higher Apgar scores than those of older mothers. Age of mother was not significantly related to hospitalizations, the need to see a physician regularly or abnormal weight. Although the number of injurious conditions and the incidence of burns were higher among the children of adolescent mothers, the effect of age of mother was not independent of other factors. The children of teenage mothers scored better than those of older mothers on the total Denver Developmental Screening Test, as well as on the Fine Motor sector. Their findings suggested that when relevant background characteristics are controlled, children of teenage mothers are as healthy and develop as well as children of older mothers.

\section{THEORETICAL FRAMEWORK AND METHODOLOGY}

\subsection{Theoretical Framework}

In this framework, we use a reduced form of reproductive health function as proposed by Rosenzweig and Schultz (1983) and applied by Mwabu (2009) to study the determinants of mother's age at first birth. Here, the demand behaviour for child health services by a mother is analyzed using a model in which the child is embedded in the utility function, this implies the demand for child health care is analyze within the framework of utility maximization behaviour of the mother. This is understood by considering the following mathematical economic formulas:

$$
\begin{aligned}
& U=U(X, Y, H) \\
& H=H(Y, Z, \mu) \\
& I=X P_{x}+Y P_{y}+Z P_{Z}
\end{aligned}
$$

From equation (1) $U$ is utility derived from consumption of goods and services (including child health), $X$ is health neutral goods that yield utility to a mother but has no direct effect on reproductive health status of the mother, $X$ is health related goods or behaviours that yield utility to the mother and also affects birth weight while $H$ is health status of the child, measured by birth weight. Equation (2) presents the reproductive health function, here $Z$ is purchased market inputs such as medical care and nutrient intake that affect child health directly, $\mu$ is the component of child health due to either genetic or environmental conditions uninfluenced by behaviours. It is also a vector summarizing all unobservable characteristics of the child, mother, household or community that affect child health.

In this study, we envisage a framework in which household utility function encompasses child health, which is captured in this study by birth weight of children up to 59 months old. According to Mwabu (2009) anthropometric indicators of child health/nutrition tend to be positively associated in many studies with a child's chances of survival, later health status, subsequent performance in school and eventually productivity as an adult worker. The household provides the environment in which individuals produces and consume health and other goods and services. In addition to providing its members with an environment for production and consumption of private and public goods, the household also provides the mechanism for intra household allocation of essential commodities such as health care, food, clothing and reproductive health 
services. This allocation mechanism is important because it determines the well-being of all household members (Ajakaiye and Mwabu (2007). Hence, the estimation of the parameters of the birthweight production function requires knowledge of inputs into the process and since inputs and outputs are jointly determined, causality might also occur in the other direction. Moreover, studies have shown that mother's age at first birth is a key determinant of health outcomes (Case et al., 2005). Therefore, we use the instrumental variable (IV) conventional method to reduce the problem of endogeneity.

Notwithstanding, as observed from the utility maximization behaviour of the mother (equation 1) and the reproductive health production function (equation 2), the mother maximizes (1) and (2) subject to the budget constraint of equation (3). In this constraint, $I$ is the exogenous income, $P x, P y, P z$ are the prices of health neutral good $X$ (clothing), health related consumer good $Y$ (quitting smoking) and health investment good $Z$ (tetanus immunization) respectively. The health investment goods are purchased only for the purpose of improving the child reproductive health, so they enter the mother's utility only through $H$. The birth weight production function (equation 2) has the property of constrained utility maximization behaviour of the mother (equation 1 and 3) (Mwabu, 2009). Equations 1-3 can be re-expressed to yield reproductive health care demand functions of the form:

$$
\begin{aligned}
& X=D x(P x, P y, P z, I, \mu) \\
& Y=D y(P x, P y, P z, I, \mu) \\
& Z=D z(P x, P y, P z, I, \mu)
\end{aligned}
$$

The effects of the changes in the prices of the three goods on health input demand can be derived from equations 4.1-4.3 since from equation (2) a change in child health can be expressed as follows; $d H=F y d Y+F z d Z+F \mu d \mu$ Here, $F y, F z, F \mu$ are the marginal products of health inputs $F y, F z, F \mu x, \quad Z$ and $\mu$ respectively computed as follows $F y=\delta H / d Y ; F z=\delta H / \delta Z ; F \mu=\delta H / \delta \mu$. From equation (2), the change in health can be related to changes in respective prices of health inputs:

$$
\begin{aligned}
& d H / d P x=F y d Y / d P x+F z d Z / d P x+F \mu d \mu / d P x \\
& d H / d P y=F y d Y / d P y+F z d Z / d P y+F \mu d \mu / d P y \\
& d H / d P z=F y d Y / d P z+F z d Z / d P y+F \mu d \mu / d P z
\end{aligned}
$$


Where $d \mu / d P i=0$, for $i=x, y$ and $z$ so that the terms $F \mu()=$.0 in equation (5) as $\mu$ is a random variable unrelated to commodity prices.

\subsection{Methodology}

Mother's age at first birth (MAFB) can affect birthweight (BW) either positively or negatively through several ways though child health is associated with MAFB and they can be jointly estimated however, each has its own interpretation. As stated in most child health literature, family health and parental socioeconomic characteristics are an important component of MAFB and poverty reduction because it shapes both present and future human capital as well as livelihood opportunities. Thus, good health at childhood does not only affect the biological growth potential, risk of morbidity and mortality in later years of life; but also engenders potential household savings on medical expenditures and releases extra-time to adult household members to take more advantage of labour market opportunities, as well as the child's capacity to learn and secure better future standards of living. In this regard, children's health can be considered an important input in the well-being production function of the household registering mainly indirect effects on household income via the extra-time, peace of mind and potential savings. The causal link of MAFB and BW can be depicted by the following structural equation:

$$
B W_{I}=w_{1} \pi_{b}+\sum_{j} v_{j} M A F B+\varepsilon_{1} j=1 \ldots . .3
$$

where, $B W_{I}$ is birth weight indicator; $M A F B$ is mother's age at first birth; $w_{1}$ is a vector of exogenous covariates; $v$ is the parameter of the potentially endogenous explanatory variable (MAFB) in the birthweight function, $\pi_{b}$ is the vector of parameters to be estimated and $\varepsilon_{1}$ is the error term that captures both random effects and unobservable variables. The estimation of the parameter $v_{j}$ would show the effect of MAFB on BW. Following Wooldridge (2002) the reduced form of MAFB generating child health estimation strategy can take the following form:

$$
M A F B=w_{2} \pi_{b w j}+w_{2} \Omega_{b w j}+\varepsilon_{2 j}
$$

Where, $w_{2}$ is a vector of exogenous instrumental variables affecting MAFB but have no direct influence on child health, $\pi_{b w j}$ and $\Omega_{b w j}$ are vectors of parameters of exogenous explanatory variables in the reduced form of MAFB function to be estimated and $\boldsymbol{\varepsilon}_{2 j}$ is the error term that captures both the random effects and other relevant but unobservable characteristics or complementary inputs. 
Even if the problem of endogeneity of MAFB is solved, our next concern is about the selection of the sample because it is possible that BW of some households especially in the rural community were not measured. Thus, when estimating the BW, there is further need to deal with potential sample selection bias because some of the BW in the 2004/2011 survey was not recorded The Heckman procedure (Heckit) is used to deal with the sample selection bias (Wooldridge, 2002), the first step in the application of the Heckit procedure is the identification of the probit equation. That is, specification of factors that influence selection of the unit of study into the estimation sample without directly affecting BW. The factors that identify the sample selection equation may not necessarily be the same as those that identify the mother's age at first birth.

To control for potential sample selection bias, the whole sample, which includes recorded BW and none recorded by choice is used. To handle the selection problem, we introduce equation (8).

$$
G=1\left(w_{1} \pi_{g}+w_{3} \Omega_{g}+\varepsilon_{3}>0\right)
$$

where, $G$ is an indicator function for the selection of the observation in to the sample, it takes the value zero when BW is not recorded, $\pi_{g}$ and $\Omega_{g}$ are vectors of parameters of exogenous explanatory variables in the sample selection equation, while $w_{3}$ is a vector of exogenous variables instrumenting for the selection of asset into the estimation sample and $\varepsilon_{3}$ is the error term that captures both the random effects and unobservable characteristics of selection.

In the recent literature, the endogenous explanatory variables are commonly referred to as "treatment variables". This terminology stresses the fact that the most credible way to measure the effect of an endogenous variable on the outcome variable of interest is to vary the endogenous variable experimentally. In an experimental setting, this variation is achieved through a random assignment of units of study into treatment and control groups. Since this variation occurs when other causal factors are held constant, it is possible to identify the effect of the characteristic on outcome variable of interest (BW). In the absence of an experiment, such a variation is achieved through an econometric procedure, with the aid of a structural model (Strauss and Thomas, 1998).

Equation (6) is the structural equation of interest that is the BW production technology whose parameters are to be estimated. Equation (8) is the linear projection of the potentially endogenous variable (MAFB), on all the exogenous variables; Equation (8) is the probit for sample selection. It is the probability of a birth weight included in the estimation sample. It captures the fact that in the DHS, some households generally did not report their birthweight. Since the houses without bithweights are excluded from equation (9), equation (8) helps correct any sample selection bias in the estimated parameters. It should also be noted that, the correction factor, derived from equation (8) is the inverse of the Mills ratio.

The instrumental variables (2SLS) model based on equations (6) and (7) will be estimated for the determinants of $\mathrm{BW}$ using the econometric software STATA 10.1. In addition, the 
heterogeneity of birth weight due to non-linear interaction of MAFB with unobservable and omitted variables could bias the estimated structural coefficients. The control function approach (Garen, 1984; Card, 2001) is used to address this issue.

As noted by Garen (1984) and Baye (2010) to take care of potential endogeneity bias, sample selection bias and non-linear interactions of unobservable variables with the observed regressors specified in the birth weight function regressors simultaneously, equation (6) can be upgraded to equation 9. This control function specification takes the form:

$$
B W_{I}=w_{1} \pi+v M A F B+\gamma_{1} \hat{\varepsilon}_{2}+\lambda I M R+\gamma_{2}\left(\hat{\varepsilon}_{2}^{*} M A F B\right)+u
$$

where, $\hat{\varepsilon}_{2}$ is fitted residual of $M A F B$, derived from the reduced form linear probability model of child health (equation 7); IMR is the hazard rate, what Heckman (1979) calls the inverse of the Mills ratio obtained after estimating the probit model for selection (equation 8$) ;\left(\hat{\mathcal{E}}_{2} * M A F B\right.$ ) is interaction of the fitted child health residual with the actual value of health status, $u$ is a composite error term comprising $\varepsilon_{1}$ and the unpredicted part of $\varepsilon_{2}$, under the assumption that $E(u)=0$ and $\pi, v, \lambda, \gamma$ are parameters to be estimated.

Exclusion restrictions are imposed on equation (9) because the set of instruments for child health status is absent from the equation. The terms $I M R, \hat{\varepsilon}_{2}$ and $\left(\hat{\varepsilon}_{2} * M A F B\right)$ in equation (9) are the control function variables because they control for the effects of unobserved factors that would otherwise contaminate the estimates of structural parameters. The reduced form MAFB residual, $\hat{\varepsilon}_{2}$ serves as the control for unobservable variables that correlate with $M A F B$. In particular, if an unobserved variable is linear in $\hat{\boldsymbol{\varepsilon}}_{2}$, it is only the constant term that is affected by the unobservable and the instrumental variable (IV) estimates of equation (9) are consistent even without the inclusion of the interaction term.

As intimated in Wooldridge (1997), the $I V$ estimates of equation (9) are unbiased and consistent only when the following conditions hold: (1) the expected value of the interaction between MAFB and its residual $\left(\hat{\varepsilon}_{2} * M A F B\right)$ is zero, or the expectation of the interaction between MAFB and its fitted residual is linear, and (2) there is no sample selection problem. However, if the correlation is non-linear, then the control function approach is required and the inclusion of the interaction term, $\left(\hat{\varepsilon}_{2} * M A F B\right)$, equation (9) purges the estimated coefficients of the effects of unobservable variables (Card, 2001; Ajakaiye and Mwabu, 2007). When the control function variables are generated via the reduced form linear probability model of demand for MAFB, which corresponds to the first-stage estimates of the $I V$ and the probit for sample selection and generation of the inverse of the Mills ratio, Ordinary Least Squares (OLS) 
regression that includes both the structural parameters and the control function variables will purge the structural estimates of potential simultaneity bias, sample selection and unobserved heterogeneity.

\section{PRESENTATION OF DATA}

From global perspectives, Demographic and Health Surveys (DHS) are nationally representative household surveys that provide data for a wide range of monitoring and impact evaluation indicators in the area of population, health, and nutrition. There are two main types of DHS: (a) Standard DHS: which have a large sample size (usually $>5$,000 households) and typically are conducted every 5 to 7 years to allow comparisons over time. (b) Interim DHS: it is focus on the collection of information on key performance monitoring indicators but may not include data for all impact evaluation measures (such as mortality rates); usually conducted between rounds of DHS and has shorter questionnaires than standard DHS. Although nationally representative, these surveys have smaller samples (usually $>2,000$ but $\leq 5$,000 households).

With regards to Cameroon, the Ministry of Economic Affairs, Programming and Regional Development is the executing agency of the DHS and it is the national institute of statistics that collects the data. The 2011 DHS was realized after three other collections for 1991, 1998 and 2004 respectively. The DHS was aimed at a national representative sample of about 11732 children, with women of reproductive age, alive and living within the selected zones of sample as well as a sub sample of about $50 \%$ of households for the men. Considering the case of the child sample characteristics, our unit of observation is the child of age $0-59$ months in 2011. The data file for each child is linked to household-level characteristics such as land holding and the amount of time women spent per day to collect water or firewood. In addition, we linked information external to the household survey to the analytic sample. The key variables derived from external data include food prices, housing prices, transportation/communication prices and rainfall.

\section{EMPIRICAL RESULTS}

\subsection{Sample Descriptive Statistics}

Following table 1 below, we observed that in the survey year 2011, the youngest woman had her first child at about 12 years while the oldest mother gave birth to her first child at about 39 years old. This age is relatively better as compare to 2004 where the oldest mother gave birth to her first child at the age of 40 . The mean birthweight for all children is $3.6 \mathrm{~kg}$, with a low-birthweight incidence of $0.6 \mathrm{~kg}(600 \mathrm{~g})$. The same data reveals only slight differences in incidences of low birthweight based on reported and measured weights. In response to birthweight questions, mothers said 15 percent of their newborns were smaller than an average child (perceived to be $<3.6 \mathrm{~kg}$ but $>2.5 \mathrm{~kg}$ ) while the highest birth weight registered in the clinics is about $6.6 \mathrm{~kg}$.

We assume that key prices (used as endogenous instruments) such as basic food prices affect the quality and quantity of food intake by households and therefore the nutritional status of mother during pregnancy. This basic food prices is particularly important in determining nutritional status because it represent the staple food in most regions in Cameroon. For instance Rice, maize, plantains, and potatoes are widely consumed in Cameroon as well as other parts of 
Africa (Greer and Thorbecke, 1986). The nutrition effects of prices of these food items depend on whether the household is a net buyer or a net seller in the food market. If a household is a net seller of plantains, an increase in the price of plantains increases the household income through the "profit effect" (Singh et al., 1986). An increase in the price of plantains increases plantains consumption if its income effect is larger than the substitution effect. Other market prices (housing, transportation and communication) have similar effects in the health of the household. The annual rainfall in millimeters for 2011 precipitation for the different regions" in Cameroon, is a factor used to capture effects of natural events on the demand for prenatal care especially vaccination and also embody the relative price effects.

The exogenous demographics reveal that most households had fathers as the head with age ranging from 17 to 98 years and few mothers working in the agricultural sector, however, most of the households lived in rural zones. Many women gave birth to twins in 2011, while mothers had slightly more girls than boys. The sample statistics for control function variables represent unobserved factors that in theory could affect birth weight in complex ways. They are included in the birthweight equation to ensure that its parameters are consistently estimated.

Table-1. Weighted Sample Statistics for short listed variables to be used in the regressions

\begin{tabular}{|c|c|c|c|c|c|}
\hline Variable & Obs & Mean & SD & Min & Max \\
\hline \multicolumn{6}{|l|}{ A) Outcome Variable } \\
\hline $\begin{array}{l}\text { Log of birth weight of children in } \\
\text { grammes }\end{array}$ & 7067 & 8.116 & 0.237 & 6.396 & 8.795 \\
\hline \multicolumn{6}{|c|}{ B) Potentially endogenous determinants of birthweight } \\
\hline $\begin{array}{l}\text { Mother's age at first birth given in } \\
\text { complete years }\end{array}$ & 11732 & 18.516 & 3.580 & 12 & 39 \\
\hline
\end{tabular}

C) Potential instruments for endogenous inputs $\left(w_{2}\right)$

\begin{tabular}{l|l|l|l|l|l}
\hline $\begin{array}{l}\text { Log of price of transportation and } \\
\text { Communication }\end{array}$ & 11732 & 5.309 & 0.091 & 5.081 & 5.406 \\
\hline Log of price of housing & 11732 & 5.176 & 0.094 & 5.062 & 5.357 \\
\hline Log of price of basic food crops & 11732 & 5.641 & 0.071 & 5.461 & 5.719 \\
\hline Log of education prices & 11732 & 5.074 & 0.071 & 4.910 & 5.137 \\
\hline $\begin{array}{l}\text { Annual rainfall in millimeters, 2011 } \\
\text { precipitation }\end{array}$ & 11732 & 1585.34 & 668.554 & 763.688 & 3589. \\
\hline
\end{tabular}

D) Exogenous demographics $\left(w_{1}\right)$

\begin{tabular}{|c|c|c|c|c|c|}
\hline $\begin{array}{l}\text { Mother's education measure in years of } \\
\text { schooling }\end{array}$ & 11732 & 4.593 & 4.046 & $\mathrm{O}$ & 17 \\
\hline Mother's age & 11732 & 28.496 & 6.975 & 15 & 49 \\
\hline Mother's age squared & 11732 & 860.673 & 423.499 & 225 & 2401 \\
\hline $\begin{array}{l}\text { Mother occupation ( } 1=\text { agriculture, } \mathrm{O} \\
\text { otherwise) }\end{array}$ & 11732 & 0.021 & 0.142 & $\mathrm{O}$ & 1 \\
\hline $\begin{array}{l}\text { Present of father in the house } \quad(1= \\
\text { present, o otherwise) }\end{array}$ & 11732 & 0.724 & 0.446 & $\mathrm{O}$ & 1 \\
\hline Father's age & 11732 & 40.059 & 11.360 & 17 & 98 \\
\hline Father's age Square & 11732 & 1733.8 & 1142.76 & 289 & 9604 \\
\hline Father's education in single years & 11732 & 5.056 & 4.871 & $\mathrm{O}$ & 17 \\
\hline $\begin{array}{l}\text { Birth of the child ( } 1=\text { twin birth, } O \\
\text { otherwise) }\end{array}$ & 11732 & 0.954 & 0.209 & O & 1 \\
\hline Sex of child (1=male, o other wise) & 11732 & 0.490 & 0.499 & $\mathrm{O}$ & 1 \\
\hline Household residence $(1=$ urban, $\mathrm{O}$ & 11732 & 0.394 & 0.488 & $\mathrm{O}$ & 1 \\
\hline
\end{tabular}




\begin{tabular}{|c|c|c|c|c|c|}
\hline \multicolumn{6}{|l|}{ otherwise) } \\
\hline \multicolumn{6}{|c|}{ E) Controls for unobservable variables } \\
\hline $\begin{array}{l}\text { Predicted age of mother at first birth } \\
\text { residual }\end{array}$ & 11732 & -0.389 & 2.519 & -10.293 & $\begin{array}{l}11.04 \\
1\end{array}$ \\
\hline $\begin{array}{l}\text { Age of mother at first birth } \times \text { its } \\
\text { predicted residual }\end{array}$ & 11732 & -4.878 & 50.861 & -247.17 & $\begin{array}{l}353.3 \\
7\end{array}$ \\
\hline Inverse of the Mills Ratio & 11732 & 0.372 & 0.173 & 0.001 & 0.609 \\
\hline $\begin{array}{l}\text { Sample size with uncensored (non- } \\
\text { missing) birth weight/Total observations } \\
\text { percentage }\end{array}$ & \multicolumn{5}{|c|}{$7067(60.237)$} \\
\hline
\end{tabular}

Source: Computed by the author from 2011 Cameroon DHS. N/B: Values in the table are presented in to three significant figures.

\subsection{Birth weight Production Technologies}

In Table 2 below; column 1 depicts OLS estimates of birthweight with endogenous inputs so that the estimates are biased. In column 2, consistent IV estimates of technology parameters are presented. While columns 3 (3A and 3B), presents the Maximum Likelihood control function estimates; the estimates are obtained controlling for simultaneous bias and heterogeneity of the birth weight. We assume that the sample on which birth weight is estimated is non-random and that the interaction between unobservable variables and the correlates of birth weight is nonlinear.

The results in table 2 show that mother's age at first birth is negatively associated with birth weight. Assuming that; the unobservable variables are uncorrelated with excluded instruments or that the correlation is linear and that the estimation sample is randomly selected from the population of interest (children of age, 0-5 years). Considering the OLS, we observed that mother's age at first birth negatively (-0.006) correlates with child health at birth. This value is bias as it does not take in to consideration the endogeneity problem and other biases.

The estimate of IV shows that mother's age at first birth is negatively (-0.063) affecting child health at birth. Unfortunately, this result may be tempered with by some simultaneous and heterogeneous bias problems. The control function result reveals that mother's age at first birth negatively correlates with child health at birth. This result implies that as the mother is aging, there is a high probability for mothers to have low birth weight children due to either high $\mathrm{BP}$ or other pre-existing health problems as noted in the medical literature (Aliyu et al., 2008). Considering $3 \mathrm{~B}$, we observed that, the problem of heterogeneity bias is check, thus, the results from the parsimonious specification of $3 \mathrm{~B}$ estimates are preferred, since the coefficient on the IMR is 9.9 percent and statistically significant at one percent level, this confirms our estimate on birth weight.

The Sargan statistic $(2.460, \mathrm{p}$-value $=0.652)$ proves that the instruments are valid and so relevant, however, looking at the Cragg-Donald F-statistic we realized that though the instrument are relevant, they are marginally weak $(6.161[18.37])$. Further, the Diagnostic tests indicate that the inputs into birth weight production function are endogenous, given that the Durbin-Wu-Hausman chi-square statistic $(18.423, p$-value $=0.0000)$ indicates that the OLS estimates are not reliable for inference. Also, the first-stage $F$ statistic on excluded instruments in $3 \mathrm{~B}$ varies from 28 to $46(p$-value $=0.0000)$ implying that, the $F$-statistics on excluded instruments 
for the input equations are marginally low, suggesting that the excluded instruments are marginally weak in this case, hence, we say the instruments are marginally weak but relevant.

The reduced form estimates in the appendix reveals that, twin birth, urban residence, mother's education, mother's age, log of educational prices and rainfall positively correlates with MAFB while variables such as; mother works in the agricultural sector, present of father in the house, sex of child, father's education, fathers age, log of food, housing, transport and communication prices negatively correlate with MAFB.

Table-2. The Birth weight Production Technology.

\begin{tabular}{|c|c|c|c|c|}
\hline \multirow[b]{2}{*}{ Variable } & \multirow[b]{2}{*}{1} & \multirow[b]{2}{*}{2} & \multicolumn{2}{|l|}{3} \\
\hline & & & A & B \\
\hline $\begin{array}{l}\text { Mother's age at first birth given in complete } \\
\text { years }\end{array}$ & $\begin{array}{l}-0.006^{* * *} \\
(-6.68)\end{array}$ & $\begin{array}{l}-0.063^{* * *} \\
(-3.74)\end{array}$ & $\begin{array}{l}-0.006^{* * *} \\
(-6.23)\end{array}$ & $\begin{array}{l}-0.005^{* * *} \\
(-6.31)\end{array}$ \\
\hline Mother works in the Agricultural sector & $\begin{array}{l}-0.014 \\
(-0.86)\end{array}$ & $\begin{array}{l}-0.025 \\
(-1.18)\end{array}$ & $\begin{array}{l}-0.023 \\
(-1.37)\end{array}$ & $\begin{array}{l}-0.022 \\
(-1.34)\end{array}$ \\
\hline Mother's Age Squared & $\begin{array}{l}-0.000 \\
(-1.03) \\
\end{array}$ & $\begin{array}{l}-0.000^{* * * *} \\
(-3.47) \\
\end{array}$ & $\begin{array}{l}-0.000 \\
(-0.94)\end{array}$ & $\begin{array}{l}-0.000 \\
(-0.96)\end{array}$ \\
\hline $\begin{array}{l}\text { Father present in the House }(1=\text { present }, 0 \\
\text { otherwise) }\end{array}$ & $\begin{array}{l}0.010^{*} \\
(1.70)\end{array}$ & $\begin{array}{l}-0.017 \\
(-1.51)\end{array}$ & $\begin{array}{l}0.016^{* *} \\
(2.48)\end{array}$ & $\begin{array}{l}0.016^{* *} \\
(2.51)\end{array}$ \\
\hline Father’s Age Square & $\begin{array}{l}0.000^{* * *} \\
(2.19) \\
\end{array}$ & $\begin{array}{r}0.000^{* * * *} \\
(2.84) \\
\end{array}$ & $\begin{array}{l}0.000 \\
(1.60) \\
\end{array}$ & $\begin{array}{l}0.000 \\
(1.63)\end{array}$ \\
\hline Birth of the child ( $1=$ twin birth, 0 otherwise $)$ & $\begin{array}{l}0.235^{* * *} \\
(19.29) \\
\end{array}$ & $\begin{array}{l}0.254^{* * *} \\
(15.52)\end{array}$ & $\begin{array}{l}0.236^{* * *} \\
(19.40)\end{array}$ & $\begin{array}{l}0.236^{* * *} \\
(19.38)\end{array}$ \\
\hline Sex of Child (1=male, 0 other wise) & $\begin{array}{l}0 . .044^{* * *} \\
(8.10)\end{array}$ & $\begin{array}{l}0.040^{* * * *} \\
(5.73)\end{array}$ & $\begin{array}{l}0.043^{* * * *} \\
(7.89)\end{array}$ & $\begin{array}{l}0.043^{* * * *} \\
(7.85)\end{array}$ \\
\hline Household residence ( $1=$ Urban, 0 otherwise) & $\begin{array}{l}-0.021^{* * *} \\
(-3.65) \\
\end{array}$ & $\begin{array}{l}-0.003 \\
(--0.41) \\
\end{array}$ & $\begin{array}{l}0.014^{* *} \\
(-2.29) \\
\end{array}$ & $\begin{array}{l}-0.015^{* *} \\
(-2.38) \\
\end{array}$ \\
\hline \multicolumn{5}{|c|}{ Predicted/pseudo residuals and interaction terms (control function variables) } \\
\hline Inverse of the Mills Ratio & $\ldots$ & $\ldots$ & $\begin{array}{l}0.100^{* * * *} \\
(4.92) \\
\end{array}$ & $\begin{array}{l}0.099^{* * * *} \\
(4.91) \\
\end{array}$ \\
\hline Age of Mother residual & & & $\begin{array}{l}-0.005^{* *} \\
(-2.55)\end{array}$ & $\begin{array}{l}-0.010^{* *} \\
(-2.09)\end{array}$ \\
\hline $\begin{array}{l}\text { Age of Mother at First Birth } \times \text { its Predicted } \\
\text { Residual }\end{array}$ & $\ldots$ & $\cdots$ & $\ldots$ & $\begin{array}{l}0.000^{*} \\
(1.90)\end{array}$ \\
\hline \multicolumn{5}{|c|}{$\begin{array}{l}\text { Tests of Joint Significance of Coefficients on Linear and Squared Terms for Parents' } \\
\text { Education and Age, } \chi^{2} / \text { F statistics (p-values) }\end{array}$} \\
\hline $\begin{array}{l}\text { Mother's educational measured in completed } \\
\text { years of schooling }\end{array}$ & \begin{tabular}{l|l|}
-0.001 \\
$(-0.7)$ \\
\end{tabular} & $\begin{array}{l}0.021^{* * * *} \\
(3.24)\end{array}$ & $\begin{array}{l}0.006^{* * *} \\
(2.98)\end{array}$ & $\begin{array}{l}0.006^{* * *} \\
(2.97)\end{array}$ \\
\hline Mother's Age & $\begin{array}{l}0.007^{* *} \\
(2.22)\end{array}$ & $\begin{array}{l}0.054^{* * * *} \\
(3.76)\end{array}$ & $\begin{array}{l}0.007^{* *} \\
(2.16)\end{array}$ & $\begin{array}{l}0.007^{* * *} \\
(2.17)\end{array}$ \\
\hline Father's Education in single years & $\begin{array}{l}0.001^{*} \\
(1.74)\end{array}$ & $\begin{array}{l}-0.001 \\
(-1.02) \\
\end{array}$ & $\begin{array}{l}0.000 \\
(0.41) \\
\end{array}$ & $\begin{array}{l}0.000 \\
(0.37)\end{array}$ \\
\hline Father's Age & $\begin{array}{l}-0.004^{* * *} \\
(-2.82)\end{array}$ & $\begin{array}{l}-0.009^{* * * *} \\
(-3.77)\end{array}$ & $\begin{array}{l}-0.003^{* *} \\
(-2.12)\end{array}$ & $\begin{array}{l}-0.003^{* *} \\
(-2.15)\end{array}$ \\
\hline Constant & $\begin{array}{l}7.942^{* * * *} \\
(151.35)\end{array}$ & $\begin{array}{l}8.211^{* * * *} \\
(79.54)\end{array}$ & $\begin{array}{l}7.827^{* * * *} \\
(138.00)\end{array}$ & $\begin{array}{l}7.831^{* * * *} \\
(137.89) \\
\end{array}$ \\
\hline$R$-Squared/(Log-likelihood) & 0.0735 & $\ldots$ & 0.0771 & 0.0773 \\
\hline Wald $\chi^{2}$ (p-value)/ F-Stat $[\mathrm{df} ; \mathrm{p}$-val $]$ & $\begin{array}{l}46.64 \\
{[12,} \\
7054 ; \\
0.0000]\end{array}$ & $\begin{array}{l}28.04[12, \\
7054 ; \\
0.0000]\end{array}$ & $\begin{array}{l}42.10[14, \\
7052 \\
0.0000]\end{array}$ & $\begin{array}{l}39.38 \\
{[15,} \\
7051 ; \\
0.0000]\end{array}$ \\
\hline
\end{tabular}




\begin{tabular}{|c|c|c|c|c|}
\hline $\begin{array}{l}\text { Weak identification test: Cragg-Donald F-Stat } \\
\text { [10\% maximal IV relative bias] }\end{array}$ & $\cdots$ & $\begin{array}{l}6.161 \\
{[18.37]}\end{array}$ & $\cdots$ & $\cdots$ \\
\hline $\begin{array}{l}\text { Sargan statistic (over identification test of all } \\
\text { instruments) }\end{array}$ & $\ldots$ & $\begin{array}{l}2.460 \\
{[0.6519]}\end{array}$ & $\cdots$ & $\ldots$ \\
\hline $\begin{array}{l}\text { Durbin-Wu-Hausman } \chi^{2} \text { test for exogeneity } \\
\text { of variables in (a) (p-value) above }\end{array}$ & $\ldots$ & $\begin{array}{l}18.423 \\
(0.0000)\end{array}$ & $\ldots$ & $\ldots$ \\
\hline Uncensored Observations & \multicolumn{4}{|l|}{7067} \\
\hline
\end{tabular}

Source: Computed by author using 2011 DHS data computed in STATA 10.1 . Notes: ***, ** and * indicate $1 \%, 5 \%$ and $10 \%$ levels of significance, respectively. N/B: Dependent variable is Birthweight in grammes; values are in three significant figures; absolute value of robust t-statistics in parentheses beneath estimates

\subsection{Birth Weight Production Function by Mother's Age Group}

From table 3 below about 8.14 percent of women of age group 15-19 gave birth to their first child, 26.22 percent of women of age group 20-24, 28.97 percent of women of age group 25-29, 18.93 percent of women of age group 30-34 and about 11.67 percent of women of age group 35-39 gave birth to their first child. This result implies that in 2011, mothers of age group 15 to 19 years registered the least births $(8.14 \%)$ followed by mothers of 35 to 39 years of age (11.67). In reality most women give birth between the ages 20 to 34 years, explaining why they have a higher percentage in 2011.

Generally, in almost all age groups, we realized that the mother's age at first birth negatively correlates with child health at birth. The result of this relationship shows that mothers of age group 35-39 years suffer more negative effects than mothers of the other age groups as they have a higher magnitude, implying that the more a woman is very young or age the greater the risk of low birthweight complications. In addition to this age group, women of age group 20-24 (-0.2 percent), 25-29 (-0.6 percent), 30-34 (-0.8 percent), 35-39 (-0.1 percent).

From the above analysis we realized three principal variables that commonly influence child health at birth, so far as MAFB is concern. These factors are: mother works in the agricultural sector, household residence and the presence of father in the house. These variables are all negatively correlated with birthweight. Everything being equal, most mothers in the agricultural sectors are located in the rural communities of Cameroon, where the level of education for mothers are low. We can therefore underscore that most women resident in the rural areas gives birth early as compare to women in the cities that are well educated.

\section{CONCLUSION}

This study is entitled: modeling the effects of mother's age at first birth on child health at birth. The objectives are: (1) investigate the implication of mother's age at first birth on birthweight, (2) examine the impact of mother's age groups on child health at birth, and (3) suggest economic policies to ameliorate the mother's age - child health relationship. We make used of the control function to determine the mother's age-birthweight relationship; the Cameroon 2011 DHS is use to estimate our result based on STATA 10.1. The control function result reveals that MAFB is negatively correlating with birthweight. The result of mothers by age group shows that the age group 35 to 39 years old is more negatively correlating with birthweight. This implies that older MAFB are proportional to low birthweight. This finding 
suggest that rates of adverse perinatal outcome, such as low birthweight, stillbirth... are linked to maternal age $35-39$ years.

We recommend that aspiring mothers should endeavour to give birth to their first child before 35 years while those already advanced in age should follow closely their prenatal and medical services. This is a major step towards poverty alleviation due to low birthweight complications.

Table-3. Parameter Estimate of Birthweight Production Function by Mother's Age Group

\begin{tabular}{|c|c|c|c|c|c|}
\hline \multirow[b]{2}{*}{ Variables } & \multicolumn{5}{|c|}{ Control Function Estimate by Age Group of Mothers } \\
\hline & $15-19$ & $20-24$ & $25-29$ & $30-34$ & $35-39$ \\
\hline Mother's age at first birth & $\begin{array}{l}-0.017^{*} \\
(-1.81)\end{array}$ & $\begin{array}{l}-0.002^{*} \\
(-1.82)\end{array}$ & $\begin{array}{l}-0.006^{* * *} \\
(-3.60)\end{array}$ & $\begin{array}{l}-0.008^{* * *} \\
(-4.87)\end{array}$ & $\begin{array}{l}-0.001^{*} \\
(-1.78)\end{array}$ \\
\hline Mother's Age Squared & $\begin{array}{l}-0.007 \\
(-0.78)\end{array}$ & $\begin{array}{l}-0.000 \\
(-0.13)\end{array}$ & $\begin{array}{l}0.002 \\
(0.68)\end{array}$ & $\begin{array}{l}-0.005 \\
(-1.56) \\
\end{array}$ & $\begin{array}{l}0.001 \\
(0.25)\end{array}$ \\
\hline $\begin{array}{l}\text { Mother works in Agricultural } \\
\text { sector }\end{array}$ & $\begin{array}{l}-0.039 \\
(-0.49)\end{array}$ & $\begin{array}{l}-0.074^{* *} \\
(-2.47)\end{array}$ & $\begin{array}{l}-0.041 \\
(-1.27)\end{array}$ & $\begin{array}{l}0.057^{*} \\
(1.88)\end{array}$ & $\begin{array}{l}-0.126^{* *} \\
(-1.98)\end{array}$ \\
\hline $\begin{array}{l}\text { Present of father in the household } \\
\text { (1= present, o otherwise) }\end{array}$ & $\begin{array}{l}0.027 \\
(0.93) \\
\end{array}$ & $\begin{array}{l}-0.005 \\
(-0.41)\end{array}$ & $\begin{array}{l}0.046^{\text {****** }} \\
(3.82)\end{array}$ & $\begin{array}{l}0.032^{* * *} \\
(2.18)\end{array}$ & $\begin{array}{l}-0.029 \\
(-1.46)\end{array}$ \\
\hline Father's Age Square & $\begin{array}{l}0.007 \\
(0.13)\end{array}$ & $\begin{array}{l}1.99 \\
(0.07)\end{array}$ & $\begin{array}{l}-0.000^{* *} \\
(-2.24)\end{array}$ & $\begin{array}{l}-0.000 \\
(-0.82)\end{array}$ & $\begin{array}{l}0.000 \\
(1.63)\end{array}$ \\
\hline $\begin{array}{l}\text { Birth of the child ( } 1=\text { twin birth, } \\
\text { o otherwise) }\end{array}$ & $\begin{array}{l}-0.005 \\
(-0.06)\end{array}$ & $\begin{array}{l}0.243^{\text {***** }} \\
(7.93)\end{array}$ & $\begin{array}{l}\text { O.263**** } \\
(13.57)\end{array}$ & $\begin{array}{l}0.253^{* * * *} \\
(9.96)\end{array}$ & $\begin{array}{l}0.022^{* * * *} \\
(7.87)\end{array}$ \\
\hline $\begin{array}{l}\text { Sex of Child ( } 1=\text { male, } 0 \text { other } \\
\text { wise) }\end{array}$ & $\begin{array}{l}0.030 \\
(1.27)\end{array}$ & $\begin{array}{l}0.041^{* * * *} \\
(3.80)\end{array}$ & $\begin{array}{l}0.045^{* * * *} \\
(4.64)\end{array}$ & $\begin{array}{l}0.055^{* * * *} \\
(4.75)\end{array}$ & $\begin{array}{l}0.065^{* * * *} \\
(4.33)\end{array}$ \\
\hline $\begin{array}{l}\text { Household residence }(1=\text { Urban, } \\
\text { o otherwise) }\end{array}$ & $\begin{array}{l}-0.052^{*} \\
(-1.89)\end{array}$ & $\begin{array}{l}-0.007 \\
(-0.60)\end{array}$ & $\begin{array}{l}-0.034^{* * * *} \\
(-2.68)\end{array}$ & $\begin{array}{l}-0.020 \\
(-1.47)\end{array}$ & $\begin{array}{l}-0.009 \\
(-0.55)\end{array}$ \\
\hline Inverse of the Mills Ratio & $\begin{array}{l}-0 . .002 \\
(-0.03)\end{array}$ & $\begin{array}{l}0.099^{* *} \\
(2.44)\end{array}$ & $\begin{array}{l}0.105^{\text {***** }} \\
(2.82)\end{array}$ & $\begin{array}{l}\text { O.187 } \\
(4.26)\end{array}$ & $\begin{array}{l}-0.032 \\
(-0.57)\end{array}$ \\
\hline $\begin{array}{l}\text { Age of Mother at first birth } \\
\text { residual }\end{array}$ & $\begin{array}{l}-0.133^{* * *} \\
(-2.22)\end{array}$ & $\begin{array}{l}0.005 \\
(0.35)\end{array}$ & $\begin{array}{l}-0.026^{* *} \\
(-2.46)\end{array}$ & $\begin{array}{l}-0.007 \\
(-0.70)\end{array}$ & $\begin{array}{l}-0.017 \\
(-1.48)\end{array}$ \\
\hline $\begin{array}{l}\text { Age of Mother at First Birth } \times \text { its } \\
\text { Predicted Residual }\end{array}$ & $\begin{array}{l}0.007^{* *} \\
(2.05)\end{array}$ & $\begin{array}{l}-0.000 \\
(-0.07)\end{array}$ & $\begin{array}{l}0.000 \\
(1.09)\end{array}$ & $\begin{array}{l}-0.000 \\
(-0.26)\end{array}$ & $\begin{array}{l}0.001^{* * *} \\
(2.00)\end{array}$ \\
\hline $\begin{array}{l}\text { Mother's education in years of } \\
\text { schooling }\end{array}$ & $\begin{array}{l}0.019^{* *} \\
(2.22)\end{array}$ & $\begin{array}{l}-0.007^{*} \\
(-1.68)\end{array}$ & $\begin{array}{l}0.018^{* * * * *} \\
(4.52)\end{array}$ & $\begin{array}{l}\text { O.125 } \\
(2.69)\end{array}$ & $\begin{array}{l}-0.007 \\
(-1.38)\end{array}$ \\
\hline Mother's Age & $\begin{array}{l}0.273 \\
(0.77)\end{array}$ & $\begin{array}{l}0.017 \\
(0.12)\end{array}$ & $\begin{array}{l}-0.109 \\
(-0.67)\end{array}$ & $\begin{array}{l}0.343 \\
(1.58)\end{array}$ & $\begin{array}{l}-0.071 \\
(-0.21)\end{array}$ \\
\hline Father's Education in single years & $\begin{array}{l}-0.007^{*} \\
(-1.88)\end{array}$ & $\begin{array}{l}0.005^{* * * *} \\
(3.32)\end{array}$ & $\begin{array}{l}-0.002^{*} \\
(-1.71)\end{array}$ & $\begin{array}{l}-0.002 \\
(-0.95)\end{array}$ & $\begin{array}{l}0.005^{* * *} \\
(2.17)\end{array}$ \\
\hline Father's Age & $\begin{array}{l}-0.007 \\
(-0.88)\end{array}$ & $\begin{array}{l}-0.001 \\
(-0.28)\end{array}$ & $\begin{array}{l}\text { O.011 } \\
(2.04)\end{array}$ & $\begin{array}{l}0.003 \\
(0.65) \\
\end{array}$ & $\begin{array}{l}-0.007 \\
(-1.30)\end{array}$ \\
\hline Constant & $\begin{array}{l}6.158^{*} \\
(1.95)\end{array}$ & $\begin{array}{l}7.738^{\text {****** }} \\
(4.90)\end{array}$ & $\begin{array}{l}9.039^{\text {****** }} \\
(4.13)\end{array}$ & $\begin{array}{l}2.276 \\
(0.66) \\
\end{array}$ & $\begin{array}{l}9.189 \\
(1.45)\end{array}$ \\
\hline$R$-Squared/(Log-likelihood) & 0.0603 & 0.0677 & 0.1193 & 0.1307 & 0.1261 \\
\hline $\begin{array}{l}\text { Wald } \chi^{2}(p \text {-value }) / \text { F-Stat }[\mathrm{df} ; \\
\text { p-val }]\end{array}$ & $\begin{array}{l}2.39[15 \\
559 \\
0.0023]\end{array}$ & $\begin{array}{l}8.90[15 \\
1837 \\
0.0000]\end{array}$ & $\begin{array}{l}18.35[15 \\
2032 ; \\
0.0000]\end{array}$ & $\begin{array}{l}13.26[15 \\
1322 ; \\
0.0000]\end{array}$ & $\begin{array}{l}7.78[15, \\
809 \\
0.0000]\end{array}$ \\
\hline Total Observations & $\begin{array}{l}575 \\
8.14 \% \\
\end{array}$ & $\begin{array}{l}1853 \\
26.22 \%\end{array}$ & $\begin{array}{l}2048 \\
28.97 \%\end{array}$ & $\begin{array}{l}1338 \\
18.93 \% \\
\end{array}$ & $\begin{array}{l}825 \\
11.67 \%\end{array}$ \\
\hline
\end{tabular}

Source: Computed by author using 2011 DHS data computed in STATA 10.1 . Notes: ***, *** and * indicate $1 \%, 5 \%$ and $10 \%$ levels of significance, respectively. N/B: Dependent variable is Birthweight in grammes; values are in three significant figures; absolute value of robust t-statistics in parentheses beneath estimates. 


\section{REFERENCES}

Ajakaiye, O. and G. Mwabu, 2007. The demand for reproductive health services: An application of control function approach. Frameworks of analysis issued as a framework paper for the collaborative project on reproductive health. Economic Growth and Poverty Reduction in Africa, AERC, Nairobi.

Alderman, H. and J.R. Behrman, 2004. Estimated economic benefits of reducing LBW in low-income countries. Philadelphia, PA: University of Pennsylvania Mimeograph (Written for Human Development Network/Nutrition, World Bank).

Battaglia, F., T. Frazier and A. Hellegers, 1963. Obstetric and pediatric complications of juvenile pregnancy. Pediatrics, 3(2): 90-102.

Baye, M., 2010. Contemporaneous household economic well-being response to preschool children health status in Cameroon. Botswana Journal of Economics, 17(2): 99-130.

Bre Art, G., H. Barros, Y. Wagener and S. Prati, 2003. Characteristics of the childbearing population in Europe. European Journal of Obstetrics Gynecology and Reproductive Biology, 1(11): 45-52.

Card, D., 2001. Estimating the return to schooling: Progress on some persistent econometric problems. Econometrica, 69(5): 1127-1160.

Carolan, M. and D. Frankowska, 2010. Advanced maternal age and adverse perinatal outcome: A review of the evidence. Midwifery, 10(7): 10-16.

Carolan, M.C., 2003. The graying of the obstetric population: Implications for the older mother. Journal of Obstetrics Gynecology and Neonatal Nursing, 3(2): 19-27.

Case A, Fertig A and Paxson, C. (2005): The Lasting Impact of Childhood Health and Circumstance, Journal of Health Economics, 2(4): 365-389.

Douglas, J.W.B., 1950. Some factors associated with prematurity. The results of a national survey. J Obstet Gynaec Brit Comm, 5(7): 100-143.

Eurostat, 2012. United nations statistical division and national statistical office of the UN, Geneva.

FAQ, 2012. Frequently ask questions by the American college of obstetricians and gynacologists, FAQ060.

Garen, J., 1984. The returns to schooling: A selectivity bias approach with a continuous choice variable. Econometrica, 52(5): 1199-1218.

Greer and Thorbecke, 1986. A methodology for measuring food poverty applied to Kenya. Journal of Development Economics, 2(4): 59-74.

Hammarberg, K. and V. Clarke, 2005. Reasons for delaying childbearing - a survey of women aged over 35 years seeking assisted reproductive technology. Australian Family Physician, 3(4): 187-189.

Hardy, J.B., D. Welcher, J. Gordon and J.R. Dallas, Long-range outcome of adolescent pregnancy. Clin Obstet Gynecol, 2(1), 1215-1232.

Heckman, J.J., 1979. Sample selection bias as specification error. Econometrica, 47(1): 153-161.

Joseph, K.S., R.M. Liston, L. Dodds, L. Dahlgren and A.C. Allen, 2007. Socioeconomic status and perinatal outcomes in a setting with universal access to essential health care services. Canadian Medical Association Journal, 17(7): 583-590.

Lobl, M., D.W. Welcher and E.D. Mellits, 1971. Maternal age and intellectual functioning of offspring. Johns Hopkins Med J, 12(8): 347-357. 


\section{Asian Journal of Economic Modelling, 2014, 2(1): 1-17}

Mortensen, L.H., F. Diderichsen, G.D. Smith and A.M. Andersen, 2009. The social gradient in birth weight at term: Quantification of the mediating role of maternal smoking and body mass index. Human Reproduction, 2(4): 2629-2635.

Mwabu, G., 2009. The production of child health in Kenya: A structural model of birth weight. Journal of African Economies Advance, 18(2): 212-260. [Accessed July 22, 2008].

Oyefara, J.1., 2010. Maternal age at first birth and childhood mortality in Yoruba society: The case of Osun State, Nigeria. Journal of International Institute for Technology and Education, 3(1): 20-43.

Rosenzweig, M.R. and T.P. Schultz, 1983. Estimating a household production function: Heterogeneity, the demand for health inputs, and their effects of birth weight. Journal of Political Economy, 91(50): 723-746.

Rothenberg, P.B. and P. Varga, 1981. The relationship between age of mother and child health and development. Journal of Public Health, 7(1): 810-817.

Rychtarikova, J., C. Gourbin, A. Sipek and G. Wunsch, 2013. Impact of parental ages and other characteristics at childbearing on congenital anomalies: Results for the Czech Republic, 2000-2007, 28(5). Available from http://www.demographic-research.org. DOI 10.4054/DemRes.

Rychtarikova, J., C. Gourbin and G. Wunsch, 2004. Paternal age and child death: The stillbirth case. European Journal of Population, 20(1): 23-33.

Singh, I., L. Squire and J. Strauss, 1986. Agricultural household models: Extension, application and policy. Baltimore: Johns Hopkins University Press.

Strauss, J. and D. Thomas, 1998. Health nutrition and economic development. Journal of Economic Literature, 36(2): 766-817.

Viau, P.A., C.A. Padula and B. Eddy, 2002. An exploration of health concerns health promotion behaviors in pregnant women over age 35. American Journal of Maternal/Child Nursing, 2(7): 328-334.

Wildschut, H.I.J., 1999. Socio-demographic factors: Age parity social class and ethnicity. In: James, D.K., Steer, P.J., Weiner, C.P., Gonik, B. (Eds.), High Risk Pregnancy. 2nd Edn., London: W.B. Saunders. pp: 39-52.

Wooldridge, J.M., 1997. On two stage least squares estimation of the average treatment effect in a random coefficient model. Economics Letters, 5(6): 129-133.

Wooldridge, J.M., 2002. Econometric analysis of cross section and panel data. MA Cambridge: MIT Press.

Wunsch, G. and C. Gourbin, 2002. Parents age at birth of their offspring and child survival. Social Biology, 49(3-4): 174-184. 
Appendix: The reduced form parameter estimate of Mother's Age at first Birth

\begin{tabular}{|c|c|}
\hline Variable & $\begin{array}{l}\text { Mother's age at first birth given in } \\
\text { complete years }\end{array}$ \\
\hline Mother's Age Squared & $-0.010^{* * * *}(-14.59)$ \\
\hline Mother works in Agricultural sector & $-0.184(-0.82)$ \\
\hline $\begin{array}{l}\text { Present of father in the household }(1=\text { present, } O \\
\text { otherwise) }\end{array}$ & $-0.512^{* * * *}(-6.17)$ \\
\hline Father's Age Square & $0.000^{* *}(2.27)$ \\
\hline Birth of the child ( $1=$ twin birth, 0 otherwise) & $0.334^{* *}(2.05)$ \\
\hline Sex of Child ( $1=$ male, $\mathrm{o}$ other wise $)$ & $-0.071(-0.98)$ \\
\hline Household residence ( $1=$ Urban, 0 otherwise) & $0.210^{* * *}(2.59)$ \\
\hline $\begin{array}{l}\text { Mother's educational, measured in completed years } \\
\text { of schooling }\end{array}$ & $0.390^{* * * *}(30.30)$ \\
\hline Mother's Age & $0.809^{* * * *}(19.01)$ \\
\hline Father's Education in single years & $-0.035^{* * *}(--4.03)$ \\
\hline Father's Age & $-0.084^{* *}(-3.98)$ \\
\hline $\begin{array}{l}\text { Log of Price of transportation and } \\
\text { Communication }\end{array}$ & $-3.205^{* * * *}(-3.50)$ \\
\hline Log of Price of housing & $-3.702^{* * *}(-3.65)$ \\
\hline Log of Price of basic food crops & $-8.532^{* * * *}(-4.72)$ \\
\hline Log of education prices & $0.000^{* *}(2.46)$ \\
\hline $\begin{array}{l}\text { Annual Rainfall in millimeters, } 2011 \text { precipitation } \\
\text { for the different regions" }\end{array}$ & $0.000^{* *}(2.46)$ \\
\hline Constant & $71.629^{* * * *}(4.15)$ \\
\hline $\boldsymbol{R}$-Squared/(Log-likelihood) & 0.2826 \\
\hline Wald $\chi^{2}(p$-value $) / \mathrm{F}$-Stat $[\mathrm{df} ; \mathrm{p}$-val $]$ & $173.54[16,7050 ; 0.0000]$ \\
\hline Total Observations & 7067 \\
\hline
\end{tabular}

Source: Computed by author using 2011 DHS data computed in STATA 10.1 . Notes: ***, ** and * indicate $1 \%, 5 \%$ and $10 \%$ levels of significance, respectively. Values are in three significant figures; absolute value of robust t-statistics in parentheses. 